\title{
Arsenic, Iron, Lead, Manganese, and Uranium Concentrations in Private Bedrock Wells in Southeastern New Hampshire, 2012-2013
}

\section{Major Findings:}

- Nearly 3 out of 10 (28 percent) water samples from 232 private bedrock wells tested in southeastern New Hampshire contained trace-metal concentrations that exceed one or more of the following standards: the U.S. Environmental Protection Agency's (EPA) maximum contaminant levels in public water supplies of 10 micrograms per liter $(\mu \mathrm{g} / \mathrm{L})$ for arsenic and $30 \mu \mathrm{g} / \mathrm{L}$ for uranium, the EPA action level of $15 \mu \mathrm{g} / \mathrm{L}$ for lead, and the EPA lifetime health advisory level of $300 \mu \mathrm{g} / \mathrm{L}$ for manganese.

- Whereas 92 percent of the study participants reported that they drink their well water, only 34 percent of those reported some type of treatment-and the most common reported systems were for the removal of iron and (or) manganese.

- As of 2010, estimates of the numbers of residents in the study area that may have private wells in bedrock aquifers that supply waters with trace-metal concentrations exceeding standards are: arsenic exceeding $10 \mu \mathrm{g} / \mathrm{L}, 49,700$ people; lead exceeding $15 \mu \mathrm{g} / \mathrm{L}, 8,600 \mathrm{people;} \mathrm{uranium}$ exceeding $30 \mu \mathrm{g} / \mathrm{L}, 7,500$ people; and manganese exceeding $300 \mu \mathrm{g} / \mathrm{L}, 14,900$ people.

\section{Introduction}

Trace metals, such as arsenic, iron, lead, manganese, and uranium, in groundwater used for drinking have long been a concern because of the potential adverse effects on human health and the aesthetic or nuisance problems that some present. Moderate to high concentrations of the trace metal arsenic have been identified in drinking water from groundwater sources in southeastern New Hampshire, a rapidly growing region of the State (Montgomery and others, 2003). During the past decade (2000-10), southeastern New Hampshire, which is composed of Hillsborough, Rockingham, and Strafford Counties (fig. 1), has grown in population by nearly 48,700 (or 6.4 percent) to 819,100 . These three counties contain 62 percent of the State's population but encompass only about 22 percent of the land area (New Hampshire Office of Energy and Planning, 2011). According to a 2005 water-use study (Hayes and Horn, 2009), about 39 percent of the population in these three counties in southeastern New Hampshire uses private wells as sources of drinking water, and these wells are not required by the State to be routinely tested for trace metals or other contaminants.

Some trace metals have associated human-health benchmarks or nonhealth guidelines that have been established by the U.S. Environmental Protection Agency (EPA)
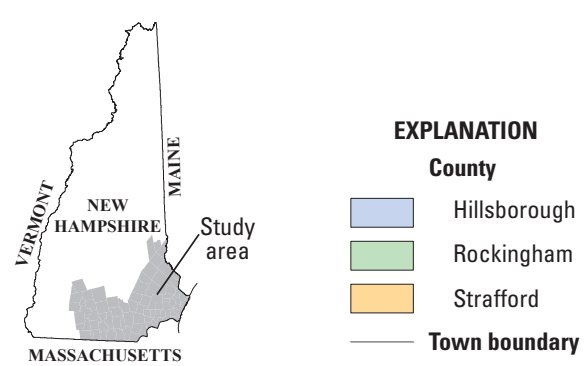

$$
0 \quad 50 \text { MILES }
$$$$
0 \quad 50 \text { KILOMETERS }
$$

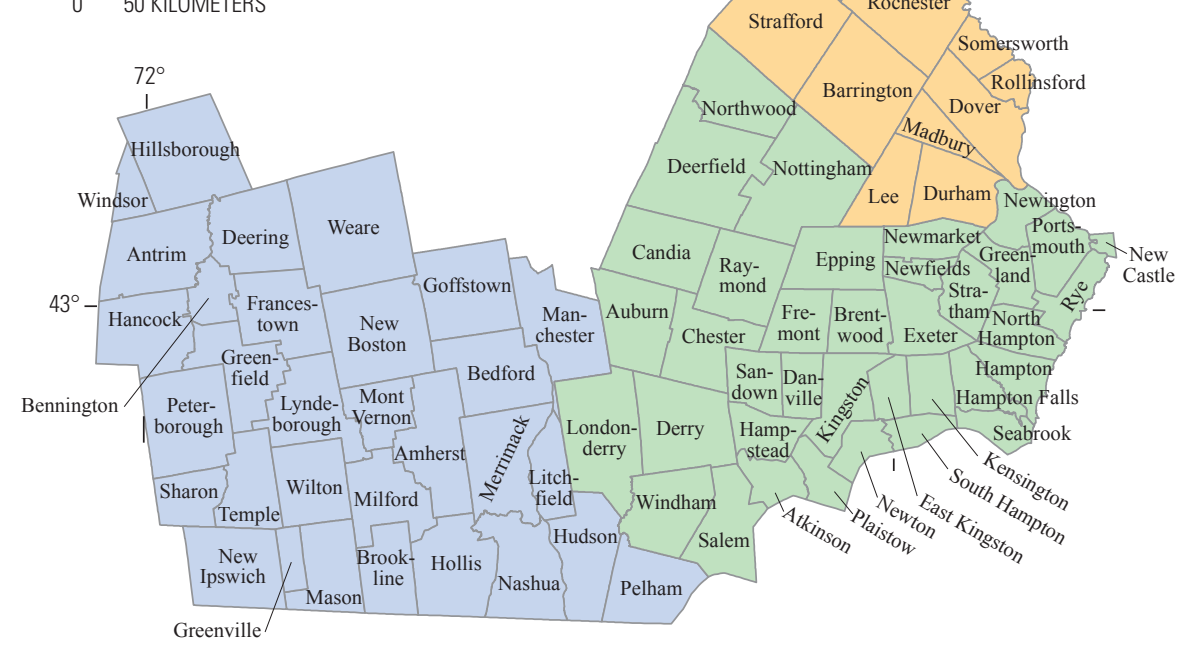

Town boundaries from U.S. Geological Survey

Digital data, 1968-88, 1:24,000;

Albers Equal-Area Conic projection

Standard parallels $29^{\circ} 30^{\prime} \mathrm{N}$ and $45^{\circ} 30^{\prime} \mathrm{N}$, central meridian $71^{\circ} 00^{\prime} \mathrm{W}$

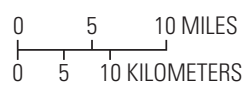

Figure 1. Locations of towns in Hillsborough, Rockingham, and Strafford counties in the southeastern New Hampshire study area. 
to regulate public water supplies. The EPA has established a maximum contaminant level (MCL) of 10 micrograms per liter $(\mu \mathrm{g} / \mathrm{L})$ for arsenic (As) and a MCL of $30 \mu \mathrm{g} / \mathrm{L}$ for uranium (U) because of associated health risks (U.S. Environmental Protection Agency, 2012). Iron ( $\mathrm{Fe}$ ) and manganese (Mn) are essential for human health, but Mn at high doses may have adverse cognitive effects in children (Bouchard and others, 2011; Agency for Toxic Substances and Disease Registry, 2012); therefore, the EPA has issued a lifetime health advisory (LHA) of $300 \mu \mathrm{g} / \mathrm{L}$ for Mn. Recommended secondary maximum contaminant levels (SMCLs) for Fe $(300 \mu \mathrm{g} / \mathrm{L})$ and $\mathrm{Mn}(50 \mu \mathrm{g} / \mathrm{L})$ were established primarily as nonhealth guidelines - based on aesthetic considerations, such as taste or the staining of laundry and plumbing fixtures - because these contaminants, at the SMCLs, are not considered to present risks to human health. Because lead $(\mathrm{Pb})$ contamination of drinking water typically results from corrosion of plumbing materials belonging to water-system customers but still poses a risk to human health, the EPA established an action level (AL) of $15 \mu \mathrm{g} / \mathrm{L}$ for Pb instead of an MCL or SMCL (U.S. Environmental Protection Agency, 2012). The 15- $\mu \mathrm{g} / \mathrm{L} \mathrm{AL}$ for $\mathrm{Pb}$ has been adopted by the New Hampshire Department of Environmental Services for public water systems, and if exceeded, the public water system must inform their customers and undertake additional actions to control corrosion in the pipes of the distribution system (New Hampshire Department of Environmental Services, 2013).

Unlike the quality of drinking water provided by public water suppliers, the quality of drinking water obtained from private wells in New Hampshire is not regulated; consequently, private wells are sampled only when individual well owners voluntarily choose to sample them. The U.S. Geological Survey (USGS), in cooperation with the EPA New England, conducted an assessment in 2012-13 to provide private well owners and State and Federal health officials with information on
Table 1. Summary of arsenic, iron, manganese, lead, and uranium concentrations in groundwater samples from private bedrock wells in southeastern New Hampshire, 2012-13.

[Water samples were collected by the study participants from untreated sources in the home. No., number; MRL, minimum reporting level; $\mu \mathrm{g} / \mathrm{L}$, micrograms per liter; Min, minimum; Max, maximum; As, arsenic; Fe, iron; Mn, manganese; $\mathrm{Pb}$, lead; $\mathrm{U}$, uranium; <, less than]

\begin{tabular}{|c|c|c|c|c|c|c|}
\hline \multirow{2}{*}{ Trace metal } & \multirow{2}{*}{$\begin{array}{c}\text { Number } \\
\text { of } \\
\text { samples }\end{array}$} & \multirow{2}{*}{$\begin{array}{c}\text { MRL, } \\
\text { in } \mu \mathrm{g} / \mathrm{L}\end{array}$} & \multirow{2}{*}{$\begin{array}{l}\text { Percent of } \\
\text { samples } \\
\text { equal to or } \\
\text { exceeding the } \\
\text { MRL }\end{array}$} & \multicolumn{3}{|c|}{ Concentration, in $\mu \mathrm{g} / \mathrm{L}$} \\
\hline & & & & Min & Median & $\operatorname{Max}$ \\
\hline Total arsenic (as As) & 232 & 1 & 57.3 & $<1$ & 1.6 & 140 \\
\hline Total iron (as Fe) & 232 & 55 & 40.5 & $<55$ & $<55$ & 16,000 \\
\hline Total manganese (as Mn) & 232 & 0.5 & 87.5 & $<0.5$ & 10.5 & 1,700 \\
\hline Total lead (as Pb) & 232 & 0.2 & 64.2 & $<0.2$ & 0.36 & 290 \\
\hline Total uranium (as U) & 232 & 1 & 49.1 & $<1$ & $<1$ & 270 \\
\hline
\end{tabular}

the distribution of trace-metal (As, Fe, $\mathrm{Pb}$, $\mathrm{Mn}$, and $\mathrm{U}$ ) concentrations in groundwater from bedrock aquifers in the three counties of southeastern New Hampshire (fig. 1). This fact sheet analyzes data from water samples collected by a randomly selected group of private well owners from the three-county study area and describes the major findings for trace-metal concentrations.

\section{Sampling Strategy}

A database maintained by the New Hampshire Department of Environmental Services containing information on private bedrock wells was used to randomly select wells from within the three-county study area (New Hampshire Department of Environmental Services, 2010). Sampling instructions and sample bottles were mailed to well owners who agreed to participate in this study. Samples were obtained from 232 participantsapproximately 30 percent of all the well owners who received a letter requesting their participation. About 143 of the participants from this study also participated in a previous arsenic study (Montgomery and others, 2003). Each study participant in the current study was asked to collect a raw-water sample from a location within the home prior to any treatment. Most of the samples (60 percent) were

\section{What is the Difference Between Milligrams per Liter and Micrograms per Liter?}

In this fact sheet, metal concentrations are reported in micrograms per liter. Another common reporting level is milligrams per liter. A concentration of 1 milligram per liter $(\mathrm{mg} / \mathrm{L})$ is equivalent to $1,000 \mu \mathrm{g} / \mathrm{L}$. Because most metals are usually detected at concentrations below $1 \mathrm{mg} / \mathrm{L}$, the use of the $\mu \mathrm{g} / \mathrm{L}$ reporting level allows a laboratory to report many results as whole numbers instead of mixed numbers in which " 0.0 " precedes the significant digits. The EPA and State health agencies generally use milligrams per liter in their literature on drinkingwater standards. For example, the EPA MCL of arsenic is $0.010 \mathrm{mg} / \mathrm{L}$, which is equivalent to $10 \mu \mathrm{g} / \mathrm{L}$. collected from a kitchen faucet, 16.5 percent were collected from an outside spigot, 15 percent from a spigot off the pressure tank, and 8.5 percent from a bathroom faucet or other location. The samples were acidified with ultrapure nitric acid by USGS personnel and then submitted to the EPA New England Regional Laboratory in Chelmsford, Massachusetts, for analysis according to EPA method 200.8 (U.S. Environmental Protection Agency, 1994). The minimum reporting levels for the studied trace metals are listed in table 1. A quality-assurance project plan was developed to assure the quality of the data obtained from this study. Forty-two quality-control (QC) samples represented 15 percent of the total samples received and included duplicate, field-blank, and standard reference samples. Online access to the environmental and QC sample results is available at: http://pubs.usgs. gov/fs/2014/3042/. Results from the analysis of the QC samples indicated no contamination issues or measurable bias.

\section{The Range of Trace-Metal Concentrations}

Arsenic concentrations in 232 groundwater samples received ranged from less than $(<) 1$ to $140 \mu \mathrm{g} / \mathrm{L}$; Fe concentrations ranged from $<55$ to $16,000 \mu \mathrm{g} / \mathrm{L}$; $\mathrm{Pb}$ concentrations ranged from $<0.2$ to $290 \mu \mathrm{g} / \mathrm{L}$; Mn concentrations ranged from $<0.5 \mu \mathrm{g} / \mathrm{L}$ to $1,700 \mu \mathrm{g} / \mathrm{L}$; and $\mathrm{U}$ concentrations ranged from $<1$ to $270 \mu \mathrm{g} / \mathrm{L}$ (table 1). Arsenic, $\mathrm{Pb}$, and Mn were detected in more than 50 percent of the samples, and $U$ was detected in 49.1 percent of the samples (table 1). Iron was detected in the fewest number of samples (40.5 percent), probably as a result of its high minimum reporting level of $55 \mu \mathrm{g} / \mathrm{L}$ (table 1). The analytical results show, on the basis of humanhealth benchmarks and nonhealth guidelines, 
that concentrations of As in 40 samples (17.2 percent) exceeded the MCL of $10 \mu \mathrm{g} / \mathrm{L}$, concentrations of $U$ in 6 samples (2.6 percent) exceeded the MCL of $30 \mu \mathrm{g} / \mathrm{L}$, concentrations of $\mathrm{Mn}$ in 12 samples (5.2 percent) exceeded the LHA of $300 \mu \mathrm{g} / \mathrm{L}$, concentrations of $\mathrm{Mn}$ in 62 samples (26.7 percent) exceeded the SMCL of $50 \mu \mathrm{g} / \mathrm{L}$, and concentrations of Fe in 39 samples (16.8 percent) exceeded the SMCL of $300 \mu \mathrm{g} / \mathrm{L}$ (table 2). Seven samples (3 percent) had $\mathrm{Pb}$ concentrations that exceeded the EPA $\mathrm{AL}$ of $15 \mu \mathrm{g} / \mathrm{L}$. Overall, 28 percent of the wells had concentrations of $\mathrm{As}, \mathrm{Mn}, \mathrm{Pb}$, or $\mathrm{U}$ that exceeded a human-health benchmark or nonhealth guideline.

\section{Trace-Metal 0ccurrence in Relation to Geology}

There were distinct spatial patterns of trace-metal concentrations greater than their respective human-health benchmarks or nonhealth guidelines within the study area (fig. 2). Data were analyzed in relation to mapped bedrock geologic units (referred to hereafter as "geologic units") identified on the State geologic map of New Hampshire (Lyons and others, 1997). Geologic units are rock types that have unique characteristics and, thus, are defined on the basis of factors such as mineral composition, age, and processes of rock formation. Trace-metal (As, Fe, Mn, and U) data from the groundwater samples were grouped according to the geologic units in which the sampled wells were located. The $\mathrm{Pb}$ data were not analyzed in relation to the geologic units because materials used for the construction of wells, pumps, spigots, and water-distribution lines can have components that contain leachable amounts of $\mathrm{Pb}$. These manmade materials are possible sources of the $\mathrm{Pb}$ detected in the water samples.

Out of 35 geologic units within the three-county study area, 21 geologic units were represented by at least one groundwater sample. Two geologic units had only 1 sample, 10 geologic units had 2 to 9 samples, and 9 geologic units had 10 or more samples (table 2). The 21 geologic units were further grouped into three bedrock categories (felsic igneous, mafic igneous, metasedimentary) based on similarities among the characteristics of the geologic units (table 2 ). The percentage of wells in each geologic unit with trace-metal concentrations exceeding human-health benchmarks or nonhealth guidelines was computed, and then geologic units were grouped together into selected percentage ranges, as shown in figure 2 .

Results of this analysis indicate that the geologic units and bedrock categories were markedly different in terms of As, Fe, $\mathrm{Mn}$, and $\mathrm{U}$ concentrations that exceeded human-health benchmarks and (or) nonhealth guidelines (table 2). None of the samples from wells in the Massabesic Gneiss Complex or Gray biotite granite had concentrations of As that exceeded $10 \mu \mathrm{g} / \mathrm{L}$, yet these geologic units had the largest percentages (8.7 and 11.1 percent, respectively) of samples with concentrations of $U$ that exceeded $30 \mu \mathrm{g} / \mathrm{L}$. In contrast, 30.3 percent of the samples from wells in the Spaulding Tonalite had As concentrations that exceeded $10 \mu \mathrm{g} / \mathrm{L}$, but none of the samples had $U$ concentrations that exceeded $30 \mu \mathrm{g} / \mathrm{L}$. The felsic igneous, mafic igneous, and metasedimentary bedrock categories each had at least one geologic unit in which 20 percent or more of the samples had concentrations of As that exceeded $10 \mu \mathrm{g} / \mathrm{L}$. Samples with high U (greater than $30 \mu \mathrm{g} / \mathrm{L}$ ) were primarily from wells in three geologic units that are part of the felsic igneous bedrock category (table 2). The largest U concentration $(270 \mu \mathrm{g} / \mathrm{L})$ was in a water sample from a well in the Two-mica granite of northern and southeastern New Hampshire. The largest As concentration $(140 \mu \mathrm{g} / \mathrm{L})$ was in a water sample from a well in the Spaulding Tonalite.

Similar geologic units can have markedly different percentages of samples with As concentrations exceeding the MCL of $10 \mu \mathrm{g} / \mathrm{L}$. For example, 11.6 percent of the water samples from wells in the Berwick Formation had concentrations of As exceeding the MCL, whereas 22.2 percent of the water samples from wells in the Berwick Formation, unnamed member, had As concentrations exceeding the MCL (table 2). The main difference between the two geologic units is that the Berwick Formation, unnamed member, contains more calc-silicate minerals than the Berwick Formation (Lyons and others, 1997). The study done by Montgomery and others (2003) had similar findings.

High concentrations of $\mathrm{Fe}$ and $\mathrm{Mn}$ occurred throughout the study area (fig. 2). However, geologic units in which more than 30 percent of water samples had Fe and $\mathrm{Mn}$ concentrations exceeding their respective SMCLs $(50 \mu \mathrm{g} / \mathrm{L}$ for $\mathrm{Mn}$ and $300 \mu \mathrm{g} / \mathrm{L}$ for $\mathrm{Fe}$ ) were predominantly from the metasedimentary bedrock category. Only samples from wells in the Concord Granite, a member of the felsic igneous bedrock category, had similarly high percentages of Mn (53.9 percent) and Fe (30.8 percent) concentrations exceeding SMCLs (table 2).

\section{Water Treatment}

More than 92 percent of the study participants reported that they use the water from their private wells as drinking water, and 34 percent of those participants who use their wells for drinking reported some type of water-treatment system. Water softeners (44 participants) and sediment filters (25 participants) were the most commonly reported treatment systems. Only four participants specifically reported treating for As; none for U or $\mathrm{Pb}$. The most common complaints reported by the participants were about problems with $\mathrm{Fe}$ and $\mathrm{Mn}$. Therefore, it is not surprising that a greater percentage of wells with high $\mathrm{Fe}$ and (or) Mn concentrations - above SMCLs at which these metals cause staining and taste problems - have a treatment system than other wells do (table 3). Among wells with As or $\mathrm{U}$ concentrations above the MCL, there is no significant difference between the wells that have a treatment system and those that do not (table 3 ). This insignificant difference indicates that owners of private bedrock wells are more likely to treat their well water for contaminants that can be seen or tasted, such as $\mathrm{Fe}$ and $\mathrm{Mn}$, than for invisible and tasteless contaminants, such as $\mathrm{U}$ or As.

\section{Human Health Implications}

High concentrations of As and $U$ in drinking water have been associated with adverse health outcomes, primarily cancers, and currently are regulated by Federal standards for public water supplies (U.S. Environmental Protection Agency, 2012). New research also has shown that children exposed to high concentrations of $\mathrm{Mn}$ in drinking water may be at risk for cognitive problems (Bouchard and others, 2011). Potential health effects from long-term exposure to $\mathrm{Pb}$ concentrations above the AL could delay physical and mental development in infants and children, cause children to show slight deficits in attention span and learning ability, and cause kidney problems and high blood pressure in adults (U.S. Environmental Protection Agency, 2012). Unlike the other trace metals described, Fe ingested from drinking water is not directly associated with adverse health effects.

In this section, an estimate of the number of people with private wells with high $\mathrm{As}, \mathrm{U}, \mathrm{Pb}$, and $\mathrm{Mn}$ concentrations is presented. According to the most current U.S. Census Bureau data (New Hampshire Office of Energy and Planning, 2011), approximately 319,000 people in 2010 obtained drinking water from private wells in the three-county study area. Recent well data from the State of 
Table 2. Summary of the percentages of water samples with arsenic, iron, manganese, and uranium concentrations exceeding humanhealth benchmarks and nonhealth guidelines, by geologic unit, from private bedrock wells in southeastern New Hampshire, 2012-2013.

[Geologic units are from Lyons and others (1997). Major bedrock categories are described in detail in Flanagan and others (2012). Color shadings indicate the percentage of wells with exceedances above concentration thresholds in ranges of $<1$ percent , 1 to 10 percent , $>10$ to 20 percent , $>20$ to 30 percent , and $>30$ percent $ـ$ MCL, enforceable U.S. Environmental Protection Agency (EPA) maximum contaminant level for public water systems; LHA, EPA lifetime health advisory level determined using EPA toxicity data and methods; SMCL, EPA secondary maximum contaminant level; >, greater than; <, less than]

\begin{tabular}{|c|c|c|c|c|c|c|c|}
\hline \multirow{4}{*}{ Geologic unit } & \multirow{4}{*}{$\begin{array}{c}\text { Number } \\
\text { of } \\
\text { samples }\end{array}$} & \multicolumn{3}{|c|}{ Human-health benchmark } & \multicolumn{2}{|c|}{ Nonhealth guideline } & \multirow{4}{*}{$\begin{array}{l}\text { Percent of } \\
\text { study area } \\
\text { underlain } \\
\text { by geologic } \\
\text { unit }^{2}\end{array}$} \\
\hline & & MCL & MCL & LHA & SMCL & SMCL & \\
\hline & & \multicolumn{5}{|c|}{$\begin{array}{l}\text { Percent of water samples with concentrations } \\
\text { (in micrograms per liter) of: }\end{array}$} & \\
\hline & & $\begin{array}{c}\text { Uranium } \\
\quad>30\end{array}$ & $\begin{array}{l}\text { Arsenic } \\
>10\end{array}$ & $\begin{array}{c}\text { Manganese } \\
>\mathbf{3 0 0}\end{array}$ & $\begin{array}{c}\text { Manganese } \\
>50\end{array}$ & $\begin{array}{l}\text { Iron } \\
>300\end{array}$ & \\
\hline \multicolumn{8}{|c|}{ Felsic igneous bedrock } \\
\hline Mesoperthitic biotite granite ${ }^{1}$ & 3 & 0 & 0 & 0 & 0 & 0 & 1 \\
\hline Kinsman Granodiorite & 20 & 0 & 20 & 5 & 20 & 20 & 8 \\
\hline Massabesic Gneiss Complex & 23 & 8.7 & 0 & 0 & 21.7 & 4.4 & 10 \\
\hline Spaulding Tonalite & 33 & 0 & 30.3 & 3 & 27.3 & 15.2 & 10 \\
\hline Concord Granite & 13 & 7.7 & 7.7 & 15.4 & 53.9 & 30.8 & 7 \\
\hline Gray biotite granite & 9 & 11.1 & 0 & 0 & 0 & 0 & 3 \\
\hline $\begin{array}{l}\text { Two-mica granite of northern and southeastern New } \\
\text { Hampshire }^{1}\end{array}$ & 2 & 50 & 50 & 0 & 0 & 0 & 2 \\
\hline
\end{tabular}

\begin{tabular}{|c|c|c|c|c|c|c|c|}
\hline \multicolumn{8}{|c|}{ Mafic igneous bedrock } \\
\hline Exeter Diorite & 10 & 0 & 50 & 0 & 10 & 20 & 3 \\
\hline \multicolumn{8}{|c|}{ Metasedimentary bedrock } \\
\hline Berwick Formation & 43 & 2.3 & 11.6 & 4.7 & 20.9 & 11.6 & 16 \\
\hline Berwick Formation, unnamed member & 19 & 0 & 22.2 & 0 & 21.1 & 10.5 & 6 \\
\hline Eliot Formation & 9 & 0 & 22.2 & 11.1 & 33.3 & 22.2 & $<1$ \\
\hline Kittery Formation & 6 & 0 & 16.7 & 0 & 16.7 & 0 & 3 \\
\hline $\begin{array}{l}\text { Rangely Formation, pink to green calc-silicate and purple } \\
\text { biotite granofels }{ }^{1}\end{array}$ & 1 & 0 & 0 & 0 & 100 & 0 & $<1$ \\
\hline Littleton Formation $^{1}$ & 2 & 0 & 50 & 0 & 50 & 0 & 2 \\
\hline Perry Mountain Formation & 8 & 0 & 12.5 & 0 & 37.5 & 25 & 6 \\
\hline Rangely Formation, undivided ${ }^{1}$ & 2 & 0 & 0 & 0 & 0 & 50 & $<1$ \\
\hline Rangely Formation, lower part & 11 & 0 & 18.2 & 18.2 & 45.5 & 45.5 & 4 \\
\hline Rangely Formation, upper part & 10 & 0 & 20 & 10 & 60 & 40 & 5 \\
\hline Rye Complex ${ }^{1}$ & 3 & 0 & 0 & 33.3 & 33.3 & 33.3 & 2 \\
\hline Smalls Falls Formation, undivided & 4 & 0 & 25 & 0 & 25 & 0 & 1 \\
\hline Madrid Formation ${ }^{1}$ & 1 & 0 & 0 & 100 & 100 & 100 & $<1$ \\
\hline Overall for the study area & 232 & 2.6 & 17.2 & 5.2 & 26.7 & 16.8 & \\
\hline
\end{tabular}

${ }^{1}$ Water-quality results from three or fewer samples do not necessarily represent the actual groundwater-quality conditions of wells in this geologic unit.

${ }^{2}$ Six percent of the three-county study area was underlain by 14 individual geologic units from which no water samples were received.

New Hampshire indicate that about 90 percent of the State's rural residents obtain their drinking water from bedrock wells (New Hampshire Department of Environmental Services, 2010). By using these U.S. Census Bureau and State of New Hampshire data and the percentages of human-health benchmark exceedances for the three-county study area (table 2), it can be estimated that in the study area 49,700 people and 7,500 people, respectively, obtain their drinking water from bedrock wells with As concentrations greater than the MCL of $10 \mu \mathrm{g} / \mathrm{L}$ and $\mathrm{U}$ concentrations greater than the MCL of $30 \mu \mathrm{g} / \mathrm{L}$. About 8,600 people may have drinking water from bedrock wells with $\mathrm{Pb}$ concentrations greater than the $\mathrm{AL}$ of $15 \mu \mathrm{g} / \mathrm{L}$, and more than 14,900 people may have drinking water with Mn concentrations that exceed the LHA of $300 \mu \mathrm{g} / \mathrm{L}$. For individual households, the likelihood of having high
As, U, or Mn concentrations depends in part on the location of the household's well within a particular geologic unit. The likelihood of having high $\mathrm{Pb}$ concentrations might depend more on the geochemical conditions of the groundwater (such as low $\mathrm{pH}$ ) and the condition of the components used in the plumbing system within the individual household. 


\section{A. Arsenic}

Percentage of wells, by grouped geologic units, with arsenic greater than 10 micrograms per liter

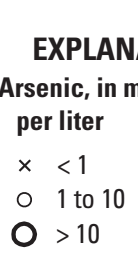

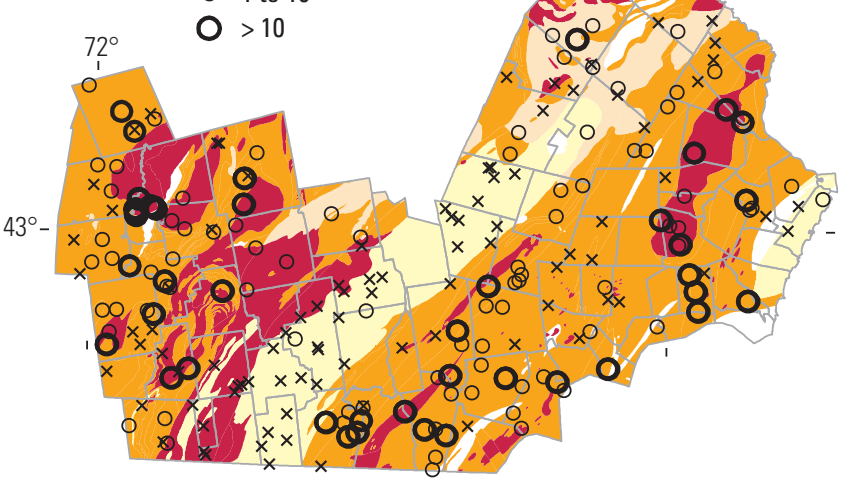

\section{Manganese}

Percent of wells, by grouped geologic units, with manganese greater than 50 micrograms per liter

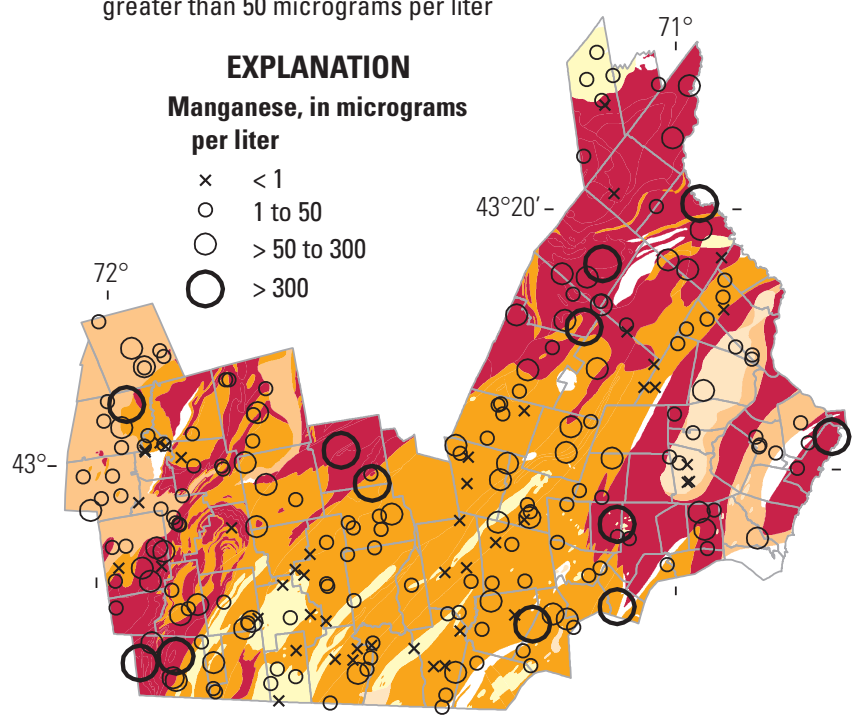

\section{B. Uranium}

Percent of wells, by grouped geologic units, with uranium greater than 30 micrograms per liter
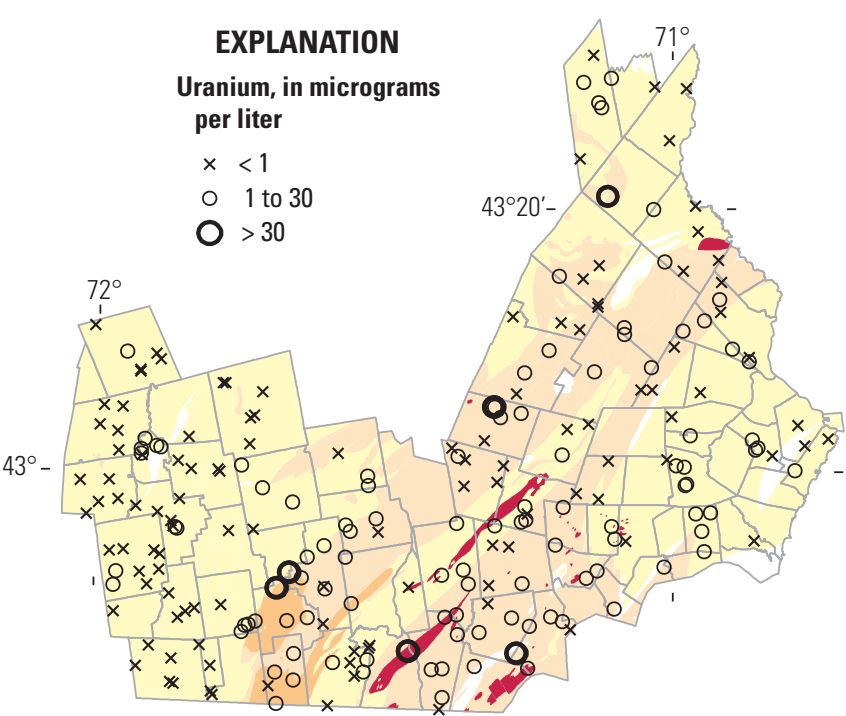

D. Iron

Percent of wells, by grouped geologic units, with iron greater than 300 micrograms per liter

\section{EXPLANATION \\ Iron, in micrograms per liter \\ $x<55$ \\ ○ 55 to 300 \\ O $>300$}

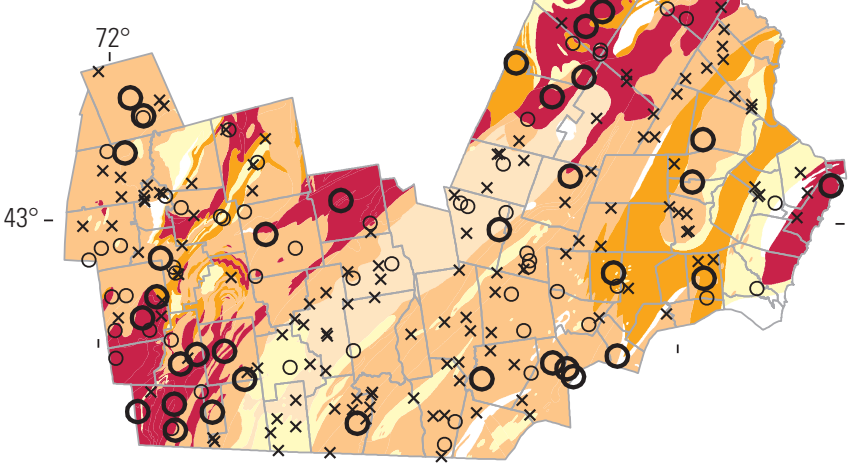

Town boundaries from U.S. Geological Survey, Digital data, 1968-88, 1:24,000;

Geologic units digitized from Lyons and others, 1997, 1:250,000;

Albers Equal-Area Conic projection, Standard parallels $29^{\circ} 30^{\prime} \mathrm{N}$ and $45^{\circ} 30^{\prime} \mathrm{N}$, central meridian $71^{\circ} \mathrm{W}$

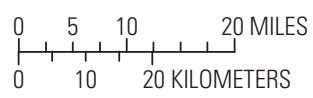

\section{EXPLANATION}

Geologic units grouped by range of percentages of wells in which trace metals exceed concentration thresholds:

Less than 1

1 to 10

Greater than 10 to 20

Greater than 20 to 30

Greater than 30

NOTE: Individual geologic unit boundaries within a group are not shown. White areas within maps indicate geologic units from which no samples were received

\section{Town boundary}

Figure 2. Geologic units in Hillsborough, Rockingham, and Strafford counties in southeastern New Hampshire, grouped by range of percentages of private bedrock wells in which trace metals exceed concentration thresholds for $A$, arsenic, $B$, uranium, $C$, manganese, and $D$, iron. Concentrations of trace metals in water samples collected from individual wells and the spatial distribution of the wells are also shown. For information on the individual geologic units in each group, see table 2. See Lyons and others (1997) for the location of individual geologic units. <, less than; > greater than. 
Table 3. Comparison of trace-metal concentrations in untreated water samples between nontreated and treated private bedrock wells in southeastern New Hampshire, 2012-13.

[ $\mu \mathrm{g} / \mathrm{L}$, micrograms per liter; $\mathrm{n}$, number; > greater than]

\begin{tabular}{|c|c|c|c|}
\hline \multirow{2}{*}{$\begin{array}{l}\text { Water-quality criteria } \\
\text { (concentrations are } \\
\text { in } \mu \mathrm{g} / \mathrm{L} \text { ) }\end{array}$} & \multirow{2}{*}{$\begin{array}{l}\text { Percent of all wells } \\
\text { in study }(n=232)\end{array}$} & \multicolumn{2}{|c|}{$\begin{array}{l}\text { Is well water treated?' } \\
\text { Percent of wells }\end{array}$} \\
\hline & & No $(n=151)$ & Yes $(n=79)$ \\
\hline Arsenic $>10$ & 17.2 & 17.2 & 16.5 \\
\hline Iron $>300$ & 16.8 & 8 & 34.2 \\
\hline Manganese $>50$ & 26.7 & 18.5 & 43 \\
\hline Lead $>15$ & 3 & 1.3 & 6.3 \\
\hline Uranium $>30$ & 2.6 & 3.3 & 1.3 \\
\hline
\end{tabular}

'Information on treatment systems is not known at two wells.

\section{Water Testing and Treatment Guidelines:}

NHDES Drinking Water and Groundwater Bureau, (603)-271-2513; email atdwgbinfo@des.nh.gov http://des.nh.gov/organization/divisions/water/ dwgb/well_testing/index.htm

\section{Acknowledgments}

The authors thank the citizens who participated in the study and the staff and contractors at the EPA New England Regional Laboratory in Chelmsford, Massachusetts, including Dan Boudreau, Doris Guzman, and Mike Dowling, for sample analysis. This study was done in cooperation with the Regional Applied Research Effort program of the EPA Office of Research and Development (ORD). The authors also thank Randall Ross (EPA ORD) for project review and coordination and Eliza Gross and Jonas Casey-Williams for their technical and editorial reviews, which greatly enhanced the quality of the manuscript.

\section{References Cited}

Agency for Toxic Substances and Disease Registry, [September] 2012, Public health statement-Manganese: U.S. Division of Toxicology and Human Health Sciences, Public Health Service, accessed November 6, 2013, at http://www.atsdr.cdc.gov/ toxprofiles/tp151-c1-b.pdf.
Ayotte, J.D., Cahillane, Matthew, Hayes, Laura, and Robinson, K.W., 2012, Estimated probability of arsenic in groundwater from bedrock aquifers in New Hampshire, 2011: U.S. Geological Survey Scientific Investigations Report 20125156, 25 p., accessed February 12, 2014, at http://pubs.usgs.gov/sir/2012/5156/.

Bouchard, Maryse F., Sauvé, Sébastien, Barbeau, Benoit, Legrand, Melissa, Brodeur, Marie-Ève, Bouffard, Thérèse, Limoges, Elyse, Bellinger, D.C, and Mergler, Donna, 2011, Intellectual impairment in school-age children exposed to manganese from drinking water: Environmental Health Perspectives, v. 119, no. 1, p. 138-43.

Flanagan, S.M., Ayotte, J.D., and Robinson, G.R., Jr., 2012, Quality of water from crystalline rock aquifers in New England, New Jersey, and New York, 1995-2007: U.S. Geological Survey Scientific Investigations Report 2011-5220, 104 p., accessed February 12, 2014, at http://pubs. usgs.gov/sir/2011/5220

Hayes, Laura, and Horn, M.A., 2009, Methods for estimating withdrawal and return flow by census block for 2005 and 2020 for New Hampshire: U.S. Geological Survey OpenFile Report 2009-1168, 32 p., accessed February 12, 2014, at http://pubs.usgs.gov/ of/2009/1168.
Lyons, J.B., Bothner, W.A., Moench, R.H., and Thompson, J.B., Jr., 1997, Bedrock geologic map of New Hampshire: U.S. Geological Survey Special Map, 2 sheets, scale $1: 250,000$.

Montgomery, D.L., Ayotte, J.D., Carroll, P.R., and Hamlin, Patricia, 2003, Arsenic concentrations in private bedrock wells in southeastern New Hampshire: U.S. Geological Survey Fact Sheet 051-03, 6 p., accessed February 13, 2014, at http://pubs. water.usgs.gov/fs-051-03.

New Hampshire Department of Environmental Services, 2010, The New Hampshire water well inventory: New Hampshire Department of Environmental Services Environmental Fact Sheet CO-GEO-7, 2 p

New Hampshire Department of Environmental Services, 2013, Overview of the Lead and Copper Rule: New Hampshire Department of Environmental Services Environmental Fact Sheet WD-DWGB-3-23, 4 p

New Hampshire Office of Energy and Planning, 2011, Population and demographic data derived from the 2010 census, by municipality and by census block: New Hampshire Office of Energy and Planning database, accessed March 23, 2011, at http://www.nh.gov/oep/datacenter/census/index.htm.

U.S. Environmental Protection Agency, 2012, 2012 Edition of the drinking water standards and Health Advisories: Washington, D.C., Office of Water, U.S. Environmental Protection Agency, EPA 822-S-12-001, 12 p. accessed February 13, 2014, at http://water.epa. gov/action/advisories/drinking/upload/ dwstandards2012.pdf.

U.S. Environmental Protection Agency, 1994, Methods for the determination of metals in environmental samples, supplement I (rev. 5.4): U.S. Environmental Protection Agency, EPA/600/R-94/111, 260 p.
For additional information, contact Office Chief, New Hampshire-Vermont Office U.S. Geological Survey New England Water Science Center 331 Commerce Way, Suite 2 Pembroke, NH 03275 (603) 226-7800; dc nh@usgs.gov http://nh.water.usgs.gov/ The data for this study are available in appendixes 1 through 5, which are available at: http://pubs.usgs.gov/fs/2014/3042
By Sarah M. Flanagan' ${ }^{\text {, Marcel Belaval2 }}$, and Joseph D. Ayotte

${ }^{1}$ U.S. Geological Survey

${ }^{2}$ U.S. Environmental Protection Agency

ISSN 2327-6916 (print)

ISSN 2327-6932 (online)

http://dx.doi.org/10.3133/fs20143042 